\title{
Social Support and Client Satisfacation with Visual Inspection Acetate Acid (VIA)
}

\author{
Reca Dwi Putri Suswanti' ${ }^{1}$, \\ Gatut Hardianto $^{2}$, \\ Samsriyaningsih Handayani ${ }^{3}$ \\ ${ }^{1}$ Study of Midwife, Faculty of \\ Medicine, University Airlangga \\ ${ }^{2}$ Departement of Obstetrics and \\ Gynecology, Faculty of \\ Medicine, University Airlangga \\ ${ }^{3}$ Departement of Public \\ Health Sciences - Preventive \\ Medicine, University \\ Airlangga \\ Email: \\ reca.dputri@gmail.com
}

Received : October $4^{\text {nd }} 2021$

Accepted : October $15^{\text {rd }} 2021$

Published : November $27^{\text {th }} 2021$

\begin{abstract}
Introduction: This study was conducted to show that early prevention and treatment of cervical cancer can save on treatment costs. Cervical cancer is one of the biggest threats to women's health. This is related to the low awareness of women who have had active sexual relations in carrying out early detection of cervical cancer so that it can increase the incidence of cervical cancer. The purpose of this study was to determine the relationship between social support and client satisfaction on IVA service satisfaction by public health center officers. Methods: This study used an observational analytic study with a retrospective cohort design. The sample size used was 70 respondents with the same distribution in each control group and the exposed group, each using 35 respondents. The sampling technique used consecutive sampling. Univariate analysis using Chi-Square test. Bivariate analysis using Spearman correlation test. Results: The results of Univariate analysis in the control group and the exposed group showed that age $(p=0.4)$, education $(p=0.136)$, occupation $(p=0.622)$, length of marriage $(\mathrm{p}=0.073)$, number of sexual partners $(\mathrm{p}=$ $0.073) .=0.602)$ and the number of children $(p=0.151)$. The results of bivariate analysis showed that husband's support $(\mathrm{p}=$ $0.735)$, mother's support $(\mathrm{p}=0.984)$, health cadre support $(\mathrm{p}=$ $0.320)$ and peer support $(p=0.725)$. There is no relationship/correlation between social support and service satisfaction. Conclusion: There are other factors that can affect the satisfaction of women of childbearing age with early detection of cervical cancer (VIA) apart from social support.
\end{abstract}

Keywords: Visual Inspection Acetic Acid (VIA), satisfaction, social Support

Copyright (C) 2021 IIK STRADA Indonesia All right reserved.

This is an open-acces article distributed under the terms of the Creative Commons AttributionShareAlike 4.0 International License.

\section{INTRODUCTION}

Visual Inspection Acetic Acid (VIA) is an examination conducted by medical personnel on the cervix who have been given acetic acid / vinegar acid 3-5\% inspecilo with the naked eye to detect early precancerous lesions (Depkes, 2014). Low awareness of women who are married / having sexual intercourse in early detection of cervical cancer will increase the incidence of cervical cancer in Indonesia. (Depkes RI, 2015). Data on the Early Detection of Cervical Cancer (VIA) from the Indonesian Ministry of Health in 2018 showed that since 2014 the VIA examination has not met the 
target, of the 6,012,729 women of childbearing age in East Java Province, only 148,875 conducted IVA in 2014, 59,332 in 2015, 149,419 in 2016, 229,084 in 2017, 25,293 in 2018 and total examinations up to 2018 amounted to $511,128(8.50 \%)$.

In East Java, women were examined by VIA as many 192,169 women (3.07\%) and positive VIA as many 9,494 women (4.94\%). The number of women aged 30-50 years as many as 178,946 (Depkes Jatim, 2017). According to Kotler (2009) and Hartono (2010) explained that the interest in re-visits is part of the client's after-service behavior, after using the service, the client will get a feeling of satisfaction or dissatisfaction. Satisfaction or dissatisfaction with the service will affect the behavior of the client next. If the client is satisfied, it will show a higher possibility to make a repeat visit. Each year, more than 300,000 women die from cervical cancer. Cervical cancer is one of the biggest threats to women's health. Prevention and early treatment of cervical cancer can save on medical costs (WHO, 2018).

Government programs related to cervical cancer early detection examination (VIA) have been regulated in The Minister of Health Regulation Number 34 since 2015 as an effort to prevent non-communicable diseases carried out nationally. Because satisfaction with VIA services is important, it is necessary to know the causative factors that affect satisfaction. One of the factors that can affect satisfaction is the ability of VIA early detection service officers in delivering examination results that are less building client trust can reduce client satisfaction. Public Health Center X and Public Health Center Y.

Based on the Health Profile in 2017 explained that the working area of Public Health Center X of 3,855 WUS, which conducted VIA examinations as many as 61 people $(1.58 \%)$ and who showed positive VIA results of 2 people (3.28\%), while for the working area of Public Health Center Y of 4,670 WUS, which conducted VIA examinations as many as 105 people $(2.25 \%)$ and who showed positive VIA results of 0 people $(0.00 \%)$. The results of the researchers' observations showed that VIA services were not carried out routinely at the Public Health Center. According to Ademuyiwa (2020) explained that social support is a determinant of satisfaction with antenatal care services.

According to Thomas (2018) said that there needs to be a strong relationship between peers and service satisfaction. Therefore, more in-depth research is needed to find out the relationship of social support with satisfaction with IVA early detection services. The purpose of this study was to find out the relationship of social support with client satisfaction with VIA services by health center officers. The study hypothesis "has a relationship between social support and client satisfaction with Visual Inspection of Acetic Acid (VIA) in Public Health Center.

\section{MATERIALS AND METHODS}

The study used observational analytical study methods with a restrospective cohort approach. The population in this study is Women of Childbearing Age (WUS) who have done early detection of VIA in Public Health Center X and Public Health Center Y. The number of samples used in the study was 35 respondents in the control group and 35 respondents in the exposed group. So, the total control group and exposed group were 70 respondents. The sampling techniques conducted in this study used consecutive sampling. The independent variable in the study was social support. The dependent variable in the study was client satisfaction with VIA services. 


\section{RESULTS}

A. General Data

In this general data will be outlined about the characteristics of respondents including age, education, work, length of marriage, number of sexual partners, and number of children.

Table 1. Descriptive Statistics of Respondent Demographics

\begin{tabular}{|c|c|c|c|c|c|c|c|c|c|c|}
\hline \multirow{2}{*}{$\begin{array}{l}\text { Characteris } \\
\text { tic }\end{array}$} & \multicolumn{5}{|c|}{ Control Group } & \multicolumn{5}{|c|}{ Exposure Group } \\
\hline & Minimum & Maximum & $\begin{array}{c}\text { Mea } \\
\mathrm{n}\end{array}$ & $\begin{array}{c}\text { Std. } \\
\text { Deviation }\end{array}$ & Modus & Minimum & Maximum & Mean & $\begin{array}{c}\text { Std. } \\
\text { Deviation }\end{array}$ & Modus \\
\hline Age & 27 & 57 & $\begin{array}{c}37,1 \\
7\end{array}$ & 7,755 & 30,32 & 29 & 58 & 44,11 & 7,307 & 40 \\
\hline $\begin{array}{l}\text { Length of } \\
\text { Marriage }\end{array}$ & 9 & 35 & $\begin{array}{c}17,1 \\
1 \\
\end{array}$ & 7,526 & 12 & 9 & 41 & 23,49 & 8,194 & 33 \\
\hline \multicolumn{11}{|c|}{ Table 2. Distribution of Cervical Cancer Risk Factors Respondents } \\
\hline \multirow{2}{*}{ Characteristics } & \multicolumn{5}{|c|}{ Control Group } & \multicolumn{5}{|c|}{ Exposure Group } \\
\hline & $\underset{\mathrm{m}}{\operatorname{Minimu}}$ & $\underset{\mathrm{m}}{\operatorname{Maximu}}$ & Mean & $\begin{array}{c}\text { Std. } \\
\text { Deviation }\end{array}$ & Modus & $\underset{\mathrm{m}}{\operatorname{Minimu}}$ & $\underset{\mathrm{m}}{\operatorname{Maximu}}$ & Mean & $\begin{array}{c}\text { Std. } \\
\text { Deviation }\end{array}$ & Modus \\
\hline $\begin{array}{c}\text { Amount of } \\
\text { Sexual Couple }\end{array}$ & 1 & 3 & 1,09 & 0,373 & 1 & 1 & 2 & 1,03 & 0,169 & 1 \\
\hline $\begin{array}{c}\text { Amount of } \\
\text { Chlidren }\end{array}$ & 1 & 3 & 1,91 & 0,702 & 2 & 1 & 6 & 2,20 & 0,901 & 2 \\
\hline
\end{tabular}

Table 3. Distribution of characteristics of respondents in the area of Public Health Center $X$ and

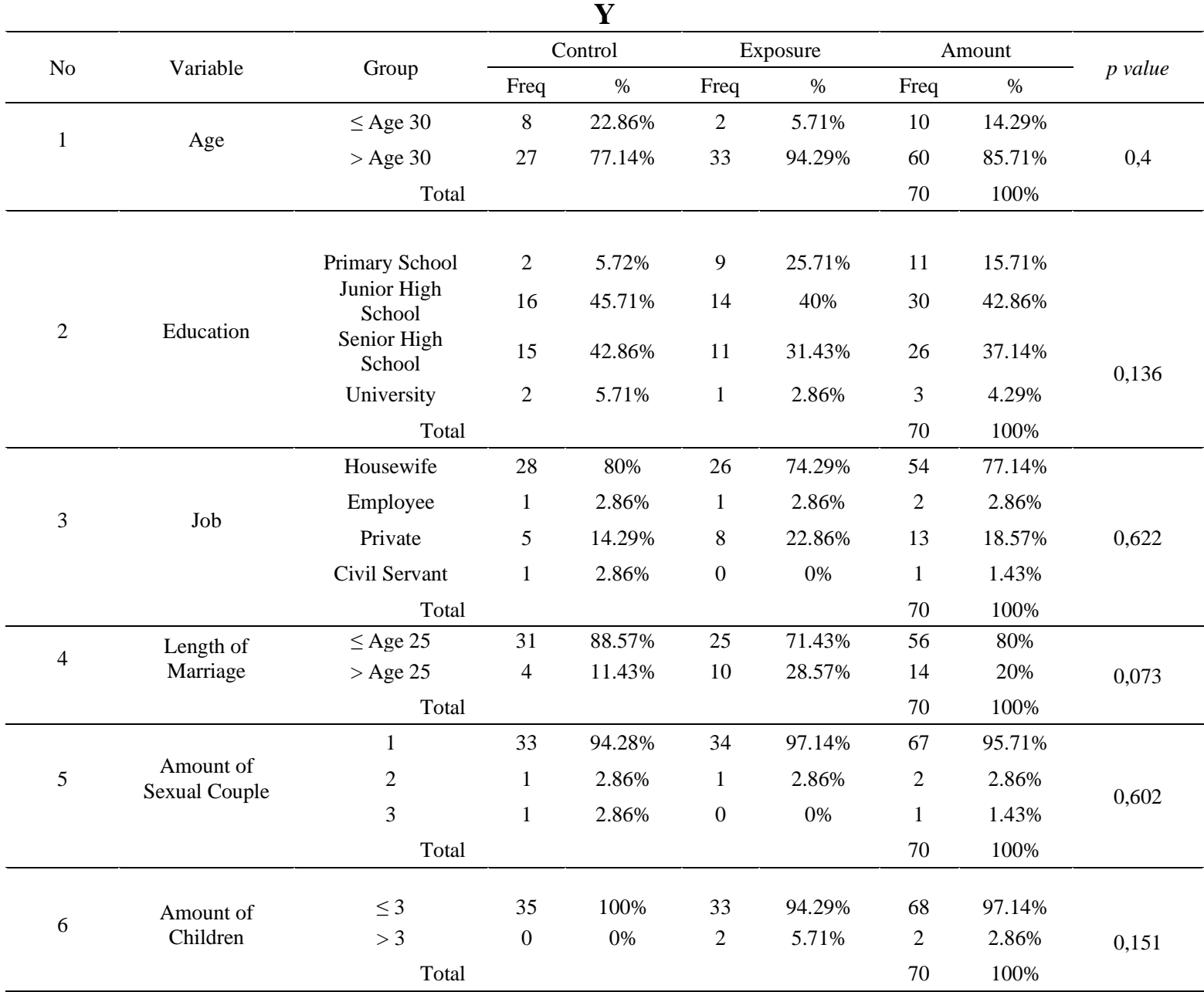


B. Special data

Social Support

Table 3. Social Support Variable Frequency Distribution

\begin{tabular}{cccc}
\hline Variable & Category & Frequency & Proportional \\
\hline \multirow{2}{*}{ Dukungan Sosial } & Get Social Support & 35 & $50 \%$ \\
& Not Getting Social Support & 35 & $50 \%$
\end{tabular}

Table 4. Descriptive Statistics Of Social Support Variables

\begin{tabular}{|c|c|c|c|c|c|c|c|c|c|c|}
\hline \multirow[b]{2}{*}{ Sosial Support } & \multicolumn{5}{|c|}{ Control Group } & \multicolumn{5}{|c|}{ Exposure Group } \\
\hline & Minimum & Maximum & Mean & $\begin{array}{c}\text { Std. } \\
\text { Deviation }\end{array}$ & Modus & Minimum & Maximum & Mean & $\begin{array}{c}\text { Std. } \\
\text { Deviation }\end{array}$ & Modus \\
\hline Husband Support & 13 & 18 & 15,743 & 1,039 & 16 & 10 & 16 & 13,714 & 1,582 & 14 \\
\hline Mom Support & 13 & 20 & 15,857 & 1,574 & 16 & 4 & 16 & 9,714 & 4,625 & 12 \\
\hline $\begin{array}{c}\text { Health Cadre } \\
\text { Support }\end{array}$ & 12 & 15 & 12,800 & 1,256 & 12 & 9 & 12 & 11,629 & 0,942 & 12 \\
\hline Peers Support & 12 & 15 & 12,543 & 1,067 & 12 & 9 & 14 & 11,400 & 1,265 & 12 \\
\hline
\end{tabular}

Table 5. Distribution of Respondent Answers

\begin{tabular}{|c|c|c|c|c|c|c|c|c|c|c|c|c|}
\hline \multirow{2}{*}{$\begin{array}{c}\text { Varia } \\
\text { ble }\end{array}$} & \multirow{2}{*}{ Indicator } & \multirow{2}{*}{ Answer } & \multicolumn{5}{|c|}{ Control Group } & \multicolumn{4}{|c|}{ Exposure Group } & \multirow[b]{2}{*}{ Modus } \\
\hline & & & Minimum & Maximum & Mean & $\begin{array}{c}\text { Standard } \\
\text { Deviation }\end{array}$ & Modus & Minimum & Maksimum & Mean & $\begin{array}{c}\text { Standard } \\
\text { Deviation }\end{array}$ & \\
\hline \multirow{14}{*}{$\begin{array}{c}\text { Social } \\
\text { Supp } \\
\text { ort }\end{array}$} & \multirow{4}{*}{$\begin{array}{l}\text { Husband } \\
\text { Support }\end{array}$} & $\mathrm{P} 1$ & 40,000 & 50,000 & 44,286 & 0,5021 & 4 & 30,000 & 50,000 & 39,429 & 0,5913 & 4 \\
\hline & & $\mathrm{P} 2$ & 30,000 & 50,000 & 36,000 & 0,5531 & 4 & 20,000 & 40,000 & 32,286 & 0,4902 & 3 \\
\hline & & P3 & 30,000 & 40,000 & 34,286 & 0,5021 & 3 & 20,000 & 40,000 & 30,286 & 0,5137 & 3 \\
\hline & & $\mathrm{P} 4$ & 30,000 & 50,000 & 42,857 & 0,5725 & 4 & 30,000 & 40,000 & 35,143 & 0,5071 & 4 \\
\hline & \multirow{4}{*}{$\begin{array}{c}\text { Mom } \\
\text { Support }\end{array}$} & P5 & 3,000 & 5,000 & 4,429 & 0,608 & 5 & 1,000 & 5,000 & 2,571 & 1,313 & 1 \\
\hline & & P6 & 3,000 & 5,000 & 3,686 & 0,631 & 4 & 1,000 & 4,000 & 2,314 & 1,105 & 3 \\
\hline & & P7 & 3,000 & 5,000 & 3,514 & 0,658 & 3 & 1,000 & 4,000 & 2,314 & 1,078 & 3 \\
\hline & & P8 & 3,000 & 5,000 & 4,229 & 0,646 & 4 & 1,000 & 5,000 & 2,514 & 1,269 & 3 \\
\hline & \multirow{3}{*}{$\begin{array}{c}\text { Health } \\
\text { Cadre } \\
\text { Support }\end{array}$} & P9 & 40,000 & 50,000 & 43,429 & 0,4816 & 4 & 30,000 & 40,000 & 38,857 & 0,3228 & 4 \\
\hline & & P10 & 40,000 & 50,000 & 42,286 & 0,4260 & 4 & 30,000 & 40,000 & 38,571 & 0,3550 & 4 \\
\hline & & P11 & 40,000 & 50,000 & 42,286 & 0,4260 & 4 & 30,000 & 50,000 & 38,857 & 0,4038 & 4 \\
\hline & \multirow{3}{*}{$\begin{array}{l}\text { Peers } \\
\text { Support }\end{array}$} & P12 & 40,000 & 50,000 & 42,571 & 0,4434 & 4 & 30,000 & 50,000 & 38,286 & 0,4528 & 4 \\
\hline & & P13 & 40,000 & 50,000 & 41,429 & 0,3550 & 4 & 30,000 & 50,000 & 38,000 & 0,4728 & 4 \\
\hline & & P14 & 40,000 & 50,000 & 41,429 & 0,3550 & 4 & 30,000 & 50,000 & 37,714 & 0,5470 & 4 \\
\hline
\end{tabular}

Based on the findings in the field, there is a diversity of very high birth mother support scores this is due to the birth mother of some respondents has died and does not live with the birth mother so that some respondents do not get support from a mother.

2. ervice Satisfaction

Table 6. Descriptive Statistics of Service Satisfaction Variables

\begin{tabular}{ccccccc}
\hline & N & Minimum & Maximum & Mean & Std. Deviation & Modus \\
\hline Service Satisfaction & 70 & 49 & 79 & 64 & 3,445 & 64 \\
\hline
\end{tabular}


Table 7. Frequency Distribution of Service Satisfaction Variables

\begin{tabular}{cccc}
\hline Variable & Category & Frequency & Proportional \\
\hline \multirow{2}{*}{ Service Satisfaction } & Satisfied & 46 & $66 \%$ \\
& Not Satisfied & 24 & $34 \%$ \\
\hline
\end{tabular}

Table 8. Distribution of Respondent Answers

\begin{tabular}{|c|c|c|c|c|c|c|c|c|c|c|c|c|}
\hline \multirow{2}{*}{ Variable } & \multirow[b]{2}{*}{ Dimention } & \multirow[b]{2}{*}{ Answer } & \multicolumn{5}{|c|}{ Control Group } & \multicolumn{5}{|c|}{ Exposure Group } \\
\hline & & & Minimum & Maximum & Mean & $\begin{array}{c}\text { Standard } \\
\text { Deviation }\end{array}$ & Modus & Minimum & Maximum & Mean & $\begin{array}{c}\text { Standard } \\
\text { Deviation }\end{array}$ & Modus \\
\hline \multirow{16}{*}{$\begin{array}{c}\text { Sevice } \\
\text { Satisfied }\end{array}$} & \multirow{3}{*}{ Tangibility } & P1 & 30,000 & 50,000 & 41,143 & 0,4038 & 4 & 30,000 & 50,000 & $\begin{array}{c}40,57 \\
1\end{array}$ & 0,4816 & 4 \\
\hline & & $\mathrm{P} 2$ & 30,000 & 50,000 & 40,857 & 0,3735 & 4 & 30,000 & 50,000 & $\begin{array}{c}40,85 \\
7\end{array}$ & 0,4453 & 4 \\
\hline & & P3 & 40,000 & 50,000 & 40,857 & 0,2840 & 4 & 30,000 & 50,000 & $\begin{array}{c}41,14 \\
3 \\
\end{array}$ & 0,4038 & 4 \\
\hline & \multirow{5}{*}{ Reability } & P4 & 30,000 & 40,000 & 36,000 & 0,4971 & 4 & 3,000 & 5,000 & 3,771 & 0,598 & 4 \\
\hline & & P5 & 40,000 & 50,000 & 40,857 & 0,2840 & 4 & 30,000 & 50,000 & $\begin{array}{c}40,57 \\
1\end{array}$ & 0,4161 & 4 \\
\hline & & P6 & 40,000 & 50,000 & 41,143 & 0,3228 & 4 & 2,000 & 5,000 & 3,914 & 0,612 & 4 \\
\hline & & $\mathrm{P} 7$ & 40,000 & 50,000 & 40,571 & 0,2355 & 4 & 20,000 & 50,000 & $\begin{array}{c}39,71 \\
4\end{array}$ & 0,5681 & 4 \\
\hline & & P8 & 40,000 & 50,000 & 40,571 & 0,2355 & 4 & 30,000 & 50,000 & $\begin{array}{c}40,28 \\
6\end{array}$ & 0,4528 & 4 \\
\hline & $\begin{array}{c}\text { Responsive } \\
\text { ness }\end{array}$ & P9 & 40,000 & 50,000 & 40,286 & 0,1690 & 4 & 30,000 & 50,000 & $\begin{array}{c}40,00 \\
0\end{array}$ & 0,3430 & 4 \\
\hline & \multirow{2}{*}{ Assurance } & $\mathrm{P} 10$ & 30,000 & 40,000 & 39,143 & 0,2840 & 4 & 30,000 & 50,000 & $\begin{array}{c}39,71 \\
4\end{array}$ & 0,2956 & 4 \\
\hline & & $\mathrm{P} 11$ & 20,000 & 40,000 & 39,143 & 0,3735 & 4 & 30,000 & 50,000 & $\begin{array}{c}40,28 \\
6\end{array}$ & 0,2956 & 4 \\
\hline & \multirow{5}{*}{ Empathy } & $\mathrm{P} 12$ & 20,000 & 50,000 & 39,429 & 0,4161 & 4 & 30,000 & 50,000 & $\begin{array}{c}40,00 \\
0\end{array}$ & 0,3430 & 4 \\
\hline & & P13 & 30,000 & 50,000 & 40,000 & 0,2425 & 4 & 30,000 & 50,000 & $\begin{array}{c}39,42 \\
9\end{array}$ & 0,3381 & 4 \\
\hline & & P14 & 30,000 & 50,000 & 40,000 & 0,2425 & 4 & 40,000 & 50,000 & $\begin{array}{c}40,57 \\
1\end{array}$ & 0,2355 & 4 \\
\hline & & P15 & 30,000 & 50,000 & 40,286 & 0,2956 & 4 & 30,000 & 50,000 & $\begin{array}{c}39,71 \\
4\end{array}$ & 0,3824 & 4 \\
\hline & & P16 & 40,000 & 50,000 & 41,714 & 0,3824 & 4 & 30,000 & 50,000 & $\begin{array}{c}40,57 \\
1\end{array}$ & 0,3381 & 4 \\
\hline
\end{tabular}

Based on the results of findings in the field found that most respondents are satisfied with the skills of officers when providing services, this is because of the first experience for respondents in conducting VIA examinations so that respondents cannot compare with other VIA examination services.

The relationship between social support and client satisfaction with Visual Inspection Acetic Acid (VIA) in Public Health Center $\mathrm{X}$ and $\mathrm{Y}$.

Table 9. Results of Cross Tabulation of Social Support Variables and Service Satisfaction

\begin{tabular}{llllllll}
\hline & $\begin{array}{l}\text { Get Social } \\
\text { Support }\end{array}$ & Percentage & $\begin{array}{l}\text { Not Getting } \\
\text { Social Support }\end{array}$ & Percentage & Amount & $p$-value & OR \\
\hline Satisfied & 22 & $63 \%$ & 24 & $69 \%$ & 46 & & \\
Not Satisfied & 13 & $37 \%$ & 11 & $31 \%$ & 24 & 0,615 & 1,289 \\
Amount & 35 & $100 \%$ & 35 & $100 \%$ & 70 & & \\
\hline
\end{tabular}

Based on the results of statistical tests using the chi-square test obtained a p value of $0.615(p>0.05)$ so that Ho was accepted, which means there is no meaningful relationship between social support for service satisfaction to visual inspection of acetic acid (VIA) at Public Health Center X and Y.

Table 10. Spearmen Correlation Analysis

\begin{tabular}{ccc}
\hline Variable & \multicolumn{2}{c}{ Social Support } \\
& Spearman's rho \\
Service Satisfaction & p-value & 0,041 \\
& & 0,738 \\
\hline
\end{tabular}

Based on the results of the Spearmen correlation test obtained a correlation value of Spearman's rho of 0.041 or it can be said that the correlation between the two variables is very small. The opportunity value $(0.738)>$ real level $(0.05)$ so that it can be decided to accept $\mathrm{H}_{0}$. So it can be concluded that there is no relationship / correlation between social support and service satisfaction. 
Tabel 11. Bivariate Analysis of The Dimensions of Social Support and Service Satisfaction

\begin{tabular}{lll}
\hline Variable & Service Satisfaction & \\
\multirow{2}{*}{ Husband Support } & Spearman's rho & 0,041 \\
& p-value & 0,735 \\
\hline \multirow{2}{*}{ Mom Support } & Spearman's rho & 0,002 \\
& p-value & 0,984 \\
\hline \multirow{2}{*}{ Health Cadre Support } & Spearman's rho & 0,121 \\
& p-value & 0,320 \\
\hline \multirow{2}{*}{ Peers Support } & Spearman's rho & 0,043 \\
& p-value & 0,725 \\
\hline
\end{tabular}

Based on the results of the Spearmen correlation test obtained spearman's rho correlation values for all four indicators $<0.5$. The odds value of the four indicators is greater than the real level $(0.05)$ so it can be decided to accept $\mathrm{H}_{0}$. So it can be concluded that there is no correlation between the four dimensions of social support and service satisfaction.

\section{DISCUSSION}

Based on the results of the study conducted stated that most respondents were satisfied with the support provided by husbands, health cadres and peers. Social support is a form of attention and protection given to a person or individual by a group or individual who has a relationship with positive things psychologically, emotionally and materially provided in the form of a relationship between humans and humans. According to Sundari (2018) explained that respondents who get good support from their husbands will conduct an VIA examination. Diversity of respondents' responses to maternal support may be a differentiating factor to satisfaction levels in both study groups. Rahma (2012) stated that the majority of WUS (Women of Childbearing Age) in Pangebatan Village of Karanglawas District of Banyumas Regency received moderate support from the family which was 39 respondents (39\%). According to Muryati (2018) stated that some respondents lacked support from health cadres, which was $59 \%$, from the findings on the ground it was found that the majority of respondents get information and support directly to follow the VIA examination program at the Health Center. According to Angriani (2019) explained that out of 121 respondents stated that the respondents received less support from friends, which was $71.9 \%$. This is in contrast to this study which states that the majority of respondents are satisfied with the peer support received because respondents get a direct invitation from peers to conduct VIA examinations together. Based on the results of the assessment of service satisfaction, it can be known that most respondents are satisfied with the five dimensions of service to the satisfaction of services received in both research groups. Client satisfaction is a form of client assessment of the services received by comparing the services received with those expected. Measurement of service satisfaction can use five dimensions of service consisting of tangibility, reability, responsiveness, ansurance.

According to Dewi (2017) explained that most respondents were dissatisfied with the antenatal service received, which was 64 people $(66.67 \%)$. The highest satisfaction dimension is the reability aspect whereas the lowest dimension is the responsiveness aspect. According to Sari (2010) stated that overall respondents were quite satisfied with the services provided. It is likely that this is what causes no difference in the dimensions of service satisfaction in these two research groups. In the results of the analysis test that has been conducted, stated that there is no relationship / correlation between the four indicators of social support and service satisfaction. Client satisfaction with the service received can be judged by how far the officer acts in accordance with the client's expectations, and the service officer must be able to pay attention to each attribute of client expectations consisting of the ratio of value / price, quality, features, guarantee or warranty, how to solve problems and client experience. Booster factors in social support can be measured by indicators of husband support, family support (birth mother), health cadre support and peer support.

According to Husni (2015) stated that family support has a significant relationship with the quality of life of breast cancer patients, low family support will affect the quality of life of patients. Based on the results of this study stated that maternal support has a diverse score that this happens because some of the respondent's mothers have died and do not live with the birth mother which makes the mother not know if the respondent did an VIA examination so that the support received by respondents is not good. According to Azizah (2016) explained that social support has a shared influence on the quality of life 
of cervical cancer patients but does not have a strong enough influence or low effect on the quality of life of cervical cancer patients. The results of this study showed that there was no difference in the satisfaction of the control group and exposure.

According to Oktarina (2009) stated that the characteristics of rural communities with different cities, most rural communities still have a low education and become housewives, while urban communities tend to have higher education so they have good knowledge compared to rural communities. Action Theory states that elderly respondents will tend to be more satisfied with the health services they receive, because they are influenced by medical personnel more responsive (reliability) to elderly respondents. According to Pratama (2014) explained that education has an influence on satisfaction, where patients with a higher level of education will have high expectations of a service received, compared to patients with low education levels who will appreciate all forms of services that have been received. Based on the results of existing research and theories, researchers assume that there are other factors that can affect the satisfaction of VIA services in addition to social support factors, including education with a $\mathrm{p}$ value of 0.136 , age with a $\mathrm{p}$ value of 0.4 , the residence of respondents who are in rural areas, and so on. Thus the social support factor of husband support, maternal support, health cadre support and peer support does not have a strong enough influence on VIA service satisfaction. In addition, one of the signs of a client satisfied with health services can be determined by a repeat visit. But a repeat visit isn't the only determining factor in satisfaction.

According to Prakash (2010) explained that satisfaction is an important indicator that can be used to measure the quality of health services. Assessment of the quality of health services can be influenced by the attitude of the officer, able to build good relationships with clients, the appearance of the health care place, the waiting time for health services, client education, and how to solve client problems. Clients who are not satisfied with the re-visit, can be affected because the local health center is the only place of free VIA service according to the work area. If the client wants to do a free IVA check elsewhere it cannot because the program is only available in the local area. And if the client is able to spend personal costs to conduct VIA examinations then the client can perform in various health services. Thus, satisfied or dissatisfied clients to the client's health services will still make repeat visits at the same health center.

\section{CONCLUSION}

Based on the results and discussion, it can be concluded that there are other factors that affect WUS satisfaction with Visual Inspection Acetic Acid (VIA) services apart from social support.

\section{REFERENCES}

Ademuyiwa, I. (2020). Social Support and Satisfication With Antenatal Care Services Among, Pregnant in Lagos State, Nigeria. African of Journal Midwifery and Women Health, Vol 14, No. 1.

Anggriani, S. (2019). Faktor Determinan Patisipasi Perempuan Beresiko dalam Pemeriksaan Visual Asam Asetat (IVA). Jurnal Kesehatan Masyarakat, Vol 7, No. 1.

Azizah, A. (2016). Hubungan Antara Dukungan Sosial dan Resiliensi Dengan Kualitas Hidup Pasien Kanker Serviks Di Rumah Sakit Dr. Soebandi.

Dewi, E. (2017). Hubungan Antara Ibu Hamil Terhadap Pelayanan Antenatal Dengan Kepuasan Kunjungan Antenatal Di Kota Surabaya.

Dinas Kesehatan Kabupaten Mojokerto. (2017). Profil Kesehatan Kabupaten Mojokerto 2017. Mojokerto, Jawa Timur, Indonesia: Pemerintah Kabupaten Mojokerto.

Dinas Kesehatan Jawa Timur. (2018). Profil Kesehatan Jawa Timur 2018. Surabaya, Jawa Timur, Indonesia: Dinas Kesehatan Provinsi Jawa Timur.

Fandy, dkk. (2015). Pelanggan Puas? Tak Cukup. Yogyakarta: Andi Offset.

Farida, dkk. (2015). Perception and satisfication of cervical cancer screening by Visual Inspection With Acetic Acid (VIA) . Meknes-Tafilalet Region, Marocco: BMC Women Health . 
Izza, A. (2019). Faktor-Faktor Yang Mempengaruhi Layanan Deteksi Dini IVA Pada WUS Di Puskesmas Kota Surabaya. Skripsi. Surabaya, Jawa Timur, Indonesia: Fakultas Kedokteran Universitas Airlangga.

Muryanti, D. (2018). Hubungan Faktor Penguat Dengan Sikap WUS Dalam Mendektesi Dini Kanker Serviks Metode IVA (Inspeksi Visual Acetat). Jurnal Skripsi. Mojokerto, Jawa Timur, Indonesia: Sekolah Tinggi Ilmu Kesehatan Majapahit.

Putri, G. (2017). Hubungan Dukungan Suami, Self Efficacy Dengan Kepuasaan Penggunaan IUD Di Puskesmas Mojo. Surabaya, Jawa Timur, Indonesia: Fakultas Kedokteran Universitas Airlangga.

Sondang, dkk. (2018). Dukungan Suami Terhadap Perilaku Wus (10-50 Tahun) dalam Melakukan Pemeriksaan IVA Di Wilayah Kerja Bondongan Tahun 2018. Jurnal Gaster.

Sundari. (2018). Pengetahuan dan Dukungan Sosial Mempengaruhi Perilaku Deteksi Dini Kanker Serviks Metode IVA . Indonesia Journal of Midwifery.

Thomas, E.C. (2018). Assosiations Between the Peer Support Relatonship, Service Satisfication and Recovery Oriented Outcomes: a Correctional Study. National Library of Medicine (NIH).

Tjicipto, dkk. (2016). Pemasaran, Efiensi dan Aplikasi. Yogyakarta : Andi.

Umami, D. (2019). Hubungan Dukungan Suami Istri dan Dukungan Petugas Kesehatan Tehadap Perilaku Pemeriksaan IVA Di Puskesemas Padang Serai. Jurnal. Fakultas Ilmu Kesehatan Universitas Dehasen Bengkulu.

Widyanti. (2018). Hubungan Dukungan Suami dengan Keikutsertaan Pemeriksaan Inspeksi Visual Asam Asetat (IVA) Pada PUS Di Puskesmas Kotagede 2 Kota Yogyakarta. Jurnal.

Wigati, A. d. (2017). Peran Dukungan Keluarga Dalam Pengambilan Keputusan Deteksi Dini Kanker Serviks . Indonesia Jurnal Kebidanan, 12-15.

Wijaya, dkk. (2018). Manajemen Kualitas Jasa. Jakarta: Indeks.

World Health Organization. (2018). Cervical Cancer.

Wulandari, N. (2015). Hubungan Layanan Keperawatan Dengan Tingkat Kepuasan Pasien Rawat Inap Di Rumah Sakit Umum Daerah (RSUD) Ungaran Kabupaten Semarang. Skripsi. Universitas Negeri Semarang. 